DOI: 10.4274/ejgg.galenos.2019.24

Eur J Geriatr Gerontol 2019;1(1):36-39

\title{
Celiac and Crohn's Disease in an Elderly Patient
}

\author{
(D) Sercan Şahutoğlu1, (D) Fatma Özge Kayhan Koçak1, () Bahattin Gökdemir1, (1) Oğuzcan Özkan², (D) Rukiye Vardar³, \\ (1) Başak Doğanavşargil4, (1) Sevnaz Şahin 1, (1) Zeliha Fulden Saraç', (1) Selahattin Fehmi Akçiçek1 \\ ${ }^{1}$ Ege University Hospital, Department of Internal Medicine, Division of Geriatrics, Izmir, Turkey \\ 2Ege University Hospital, Department of Internal Medicine, Izmir, Turkey \\ ${ }^{3}$ Ege University Hospital, Department of Internal Medicine, Division of Gastroenterology, Izmir, Turkey \\ ${ }^{4}$ Ege University Hospital, Department of Pathology, Izmir, Turkey
}

\section{Abstract}

One of the causes of chronic diarrhea in the elderly is Celiac disease, which is an autoimmune disease that particularly common in children and young adults as well as among the elderly population. Diagnosis is often delayed due to atypical presentation in the elderly. There are only a few studies in the literature linking Celiac disease to inflammatory bowel disease. In the present study, we aimed to draw attention to the rare coexistence of Celiac disease and Crohn's disease presenting with chronic diarrhea and severe malnutrition in a geriatric patient.

Keywords: Celiac disease, diarrhea, Crohn's disease

\section{Introduction}

The causes of chronic diarrhea vary according to the socioeconomic status of the population. Chronic diarrhea is frequently associated with bacterial, mycobacterial and parasitic infections in developing countries. In developed countries it is caused by irritable bowel disease, inflammatory bowel disease, chronic infections and malabsorption syndromes. Celiac disease, which is one of the malabsorption syndromes, is often underdiagnosed. It is an autoimmune disease caused by an immun response to the gliadin found in gluten. Incidence of the disease in the population is around one percent $(1,2)$, with the first peak being experienced between the first 8-12 months of life, and the second peak seen in the 3-4 decades (3). Although more common in children and young adults, an increase has been seen in the rate of detection in the elderly population $(4,5)$, and studies have shown that in some countries, 25 percent of Celiac patients receive their first diagnosis in the seventh decade $(1,6,7)$. Celiac disease affects primarily the intestinal system, although it can manifest in a very different clinic in the presence of extra-intestinal symptoms. Classical findings include chronic diarrhea, weight loss, and nutrient deficiencies such as iron and calcium, while exra-intestinal findings include anemia, osteoporosis, increased transaminase levels, neurological symptoms and infertility.

There are a number of studies reporting Celiac disease accompanying inflammatory bowel disease. We present a rare case of Celiac disease and Crohn's disease in the geriatric age group. Our goal is to emphasize Celiac disease from the causes of malnutrition, in that it can be underdiagnosed.

\section{Case Presentation}

A 72-year-old female patient visited our hospital with complaints of malaise, nausea, diarrhea and appetite loss. She had complained of diarrhea for seven years. The diarrhea was watery, 9-10 times a day and bloodless. Over the last five years, she has lost more than 20 kilograms. Her medical history includes osteoporosis, psoriasis and a cholecystectomy, although there is no known family history of gastrointestinal disorders. She had psoriasis and treated with methotrexate until 2010. Her medication includes a calcium preparation and bisphosphonate. On examination, temperature was recorded at $36.5^{\circ} \mathrm{C}$, heart rate 102 beats per minute and blood pressure was of $95 / 60 \mathrm{mmHg}$. The patient's appearance was cachectic and dehydrated. She measured $148 \mathrm{~cm}$ tall, 28 kilograms in weight and body mass

Address for Correspondence: Sercan Şahutoğlu MD, Ege University Hospital, Department of Internal Medicine, Division of Geriatrics, İzmir, Turkey Phone: +90 5558290746 E-mail: dr.sercansahutoglu@hotmail.com ORCID: orcid.org/0000-0002-9217-5945

Received: Mar 19, 2019 Accepted: Apr 21, 2019

Cite this article as: Şahutoğlu S, Kayhan Koçak FÖ, Gökdemir B, Özkan O, Vardar R, Doğanavşargil B, Şahin S, Saraç ZF, Akçiçek SF. Celiac and Crohn's Disease in an Elderly Patient. Eur J Geriatr Gerontol 2019;1(1):36-39

๑Copyright 2019 by the Academic Geriatrics Society / European Journal of Geriatrics and Gerontology published by Galenos Publishing House. 
index was $12.7 \mathrm{~kg} / \mathrm{m}^{2}$. She had a palpable liver edge $4 \mathrm{~cm}$ below the right costal margin and her skin was pale; other system examinations were normal. Laboratory studies revealed a serum sodium level of $124 \mathrm{mEq} / \mathrm{L}$, potassium $1.8 \mathrm{mEq} / \mathrm{L}$, phosphorus 1.2 $\mathrm{mg} / \mathrm{dL}$, calcium $4.3 \mathrm{mg} / \mathrm{dL}$, albumin $2.4 \mathrm{~g} / \mathrm{dL}$, Ast $43 \mathrm{U} / \mathrm{L}$, Alt 56 $\mathrm{U} / \mathrm{L}$ and 25 hydroxyvitamin $\mathrm{D} 12 \mathrm{nmol} / \mathrm{L}$ (Table 1). Celiac markers Anti-endomysium IgA $(+++)$, Tissue transglutaminase IgA $98 \mathrm{U} / \mathrm{mL}$ (reference range $0-10 \mathrm{U} / \mathrm{mL}$ ) and Anti-deamidated gliadin IgA $41 \mathrm{U} / \mathrm{mL}$ (reference range $0-10 \mathrm{U} / \mathrm{mL}$ ) were positive. A gastroscopic examination revealed hyperemic antrum, a mildly pale bulbi duodeni and occasional atrophy areas (Figure 1).

Pathological examination showed villous blunting, villous flattening, crypt hyperplasia and a small area of gastric metaplasia in both bulbus and duodenum mucosa. Increased intraepithelial CD3 positive T-lymphocyte infiltration exceeding 40 lymphocyte/100 enterocyte was also noted which was compatible with Celiac disease.

Colonoscopy revealed a $20 \mathrm{~mm}$ diameter lesion on the pili that is suspicious for a ulcerovegetan lateral spreading tumor in caecum, and a number of white exudate ulcers measuring between 3 and $15 \mathrm{~mm}$ in diameter in ascending colon, hepatic flexure, transverse colon, splenic flexure, descending colon, and sigmoid column. However, no neoplastic lesion but only pseudopolypoid ulcerated and regenerated mucosa was observed in pathological examination. Ileocecal biopsy also showed an ulcerated mucosa while the other parts of colon were normal.

Magnetic resonance enteroclisis reported an increase in number of pleats and wall thickness of intestinal segments in axial sections passing through inferior of the umblicus (Figure 2).

Celiac disease was diagnosed and Crohn's disease was suspected clinically. Crohn disease activity index was 336 points at admission time. A gluten-free diet started with prednol $20 \mathrm{mg} /$ day, oral nutritional support was added. Potassium, vitamin $D_{\text {, }}$

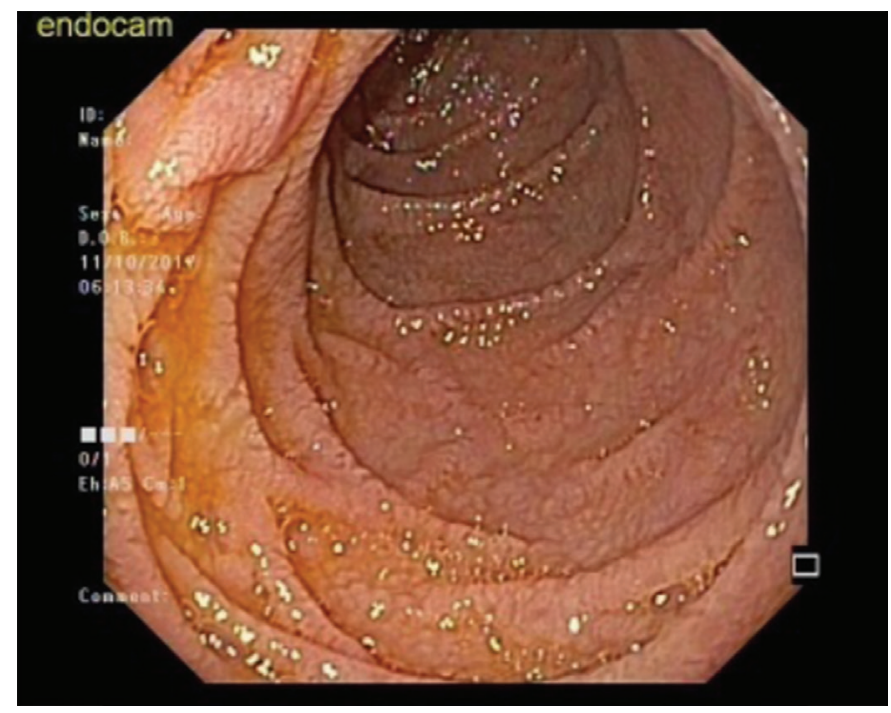

Figure 1. Second segment of duodenum vitamin $\mathrm{K}$ and vitamin E were given. After vitamin $\mathrm{K}$ replacement, the INR level returned to normal. Mesalazine $500 \mathrm{mg} 3 \times 2$ / day peroral and Methotrexate $12.5 \mathrm{mg} /$ week were added. The patient was discharged when her symptoms diminished. She weighed $41 \mathrm{~kg}$, her body mass index was $18.71 \mathrm{~kg} / \mathrm{m}^{2}$ and Crohn disease activity index was 88 points at the time of discharge. Her laboratory results returned to normal range when she discharged (Table 1). At outpatient follow up prednol dosage was reduced
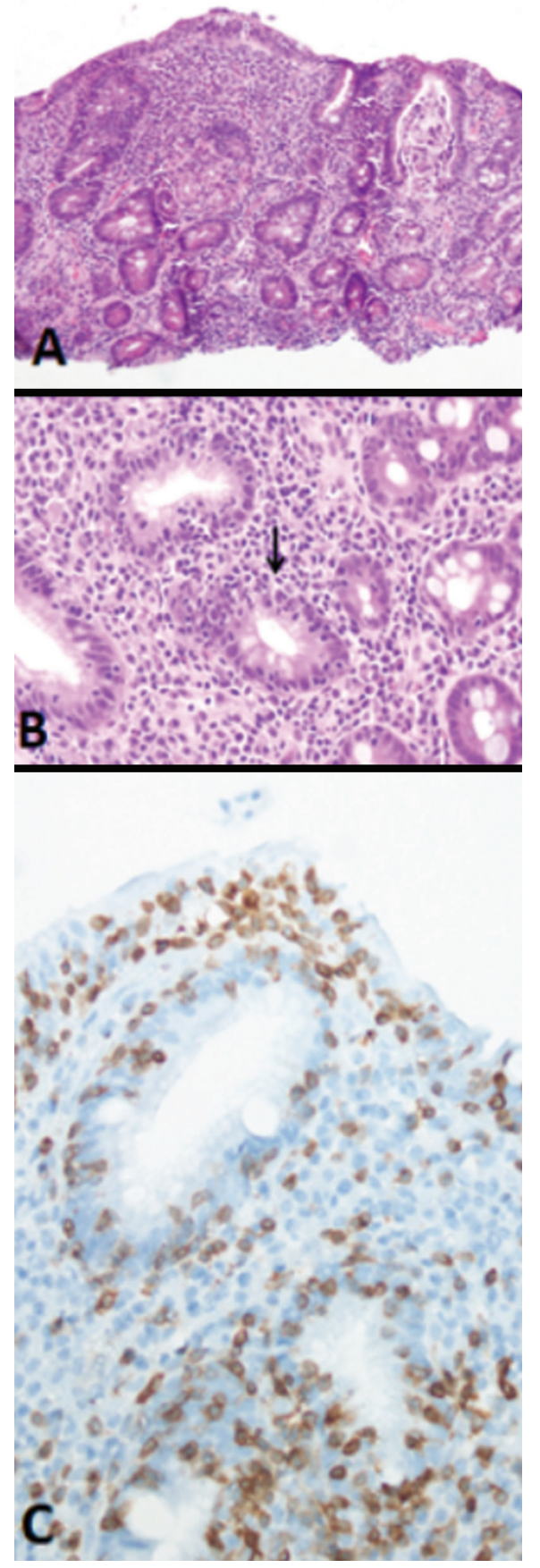

Figure 1. Bulbus biopsy. A) Flattened villi and crypts hiper plasia. (Haematoxylin and eosin, x4), B) Intraepithelial lymphocyte infiltration (arrow) (Haematoxylin and eosin, x20), C) CD3 (+) T-lymphocytes infiltration in the surface epithelium and glands exceeding $x 40$ lymphocytes /100 enterocyte (anti CD3 antibody, x20) 
and stopped. She uses mesalazine and methotrexate for 1.5 years and she is asymptomatic now.

\section{Discussion}

There have been a number of studies associating Celiac disease with inflammatory bowel disease, although the prevalence is not fully known (8-13). Yang et al. (13) found
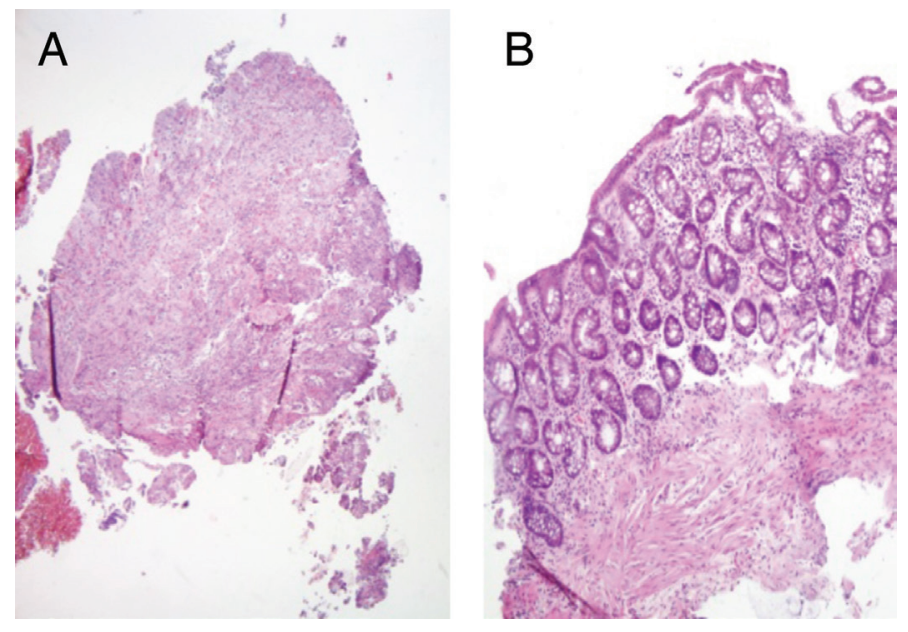

Figure 2. A) Ileocecal biopsy. The mucosa is ulcerated. Normal mucosa is not visible. (Haematoxylin and eosin, $\mathrm{x4}$ ). B) Normal mucosa in other parts of the colon (Haematoxylin and eosin, $x 4$ ) that inflammatory bowel disease was more common in Celiac disease patients than in the general population (13). In another study investigating this association, the prevalence of inflammatory bowel disease in Celiac disease patients was found to be 10 times higher than the control group (14). A prospective study in 2005 found that Celiac disease was more common in those with Crohn's disease, while another study found that Crohn's disease was more common in those who had Celiac disease $(15,16)$. There have also been studies emphasizing that the prevalence of Celiac disease is similar in those with inflammatory bowel disease and in the general population (17). There is a lack of consensus in the literature regarding the association between inflammatory bowel disease and Celiac disease.

In our patient, chronic diarrhea had been accompanied by malnutrition for the last one year, resulting in serious weight loss. The patient was $28 \mathrm{~kg}$ at the time of hospital admission. Studies have shown that involuntary weight loss is associated with increased mortality in elderly patients. It is known that five percent weight loss in three years is associated with increased mortality.

There may be many reasons for involuntary weight loss in old age, with malignant disease, psychological and social problems, gastrointestinal problems and end organ failure being just

\begin{tabular}{|c|c|c|c|}
\hline Variable & Reference Range & Results & Results at hospital discharge time \\
\hline Hemoglobin $(\mathrm{g} / \mathrm{dL})$ & $11.7-16.1$ & 11.9 & 11.9 \\
\hline Hematocrit (\%) & $35-47$ & 31.7 & 34.9 \\
\hline White cell count $(103 / \mu \mathrm{L})$ & $4.5-11.0$ & 7.580 & 8.56 \\
\hline Platelet $(103 / \mu \mathrm{L})$ & $150-450$ & 293 & 412 \\
\hline Sodium (mEq/L) & $136-145$ & 124 & 136 \\
\hline Potassium (mEq/L) & $3.5-5$ & 1.8 & 4.3 \\
\hline Chloride (mEq/L) & $96-110$ & 86 & 103 \\
\hline Urea $(\mathrm{mg} / \mathrm{dL})$ & $10-50$ & 11 & 22 \\
\hline Creatinine $(\mathrm{mg} / \mathrm{dL})$ & $0.6-1.1$ & 0.55 & 0.5 \\
\hline 25 hydroxyvitamin D (nmol/L) & 10-19 light-medium & 12 & 33 \\
\hline Aspartate aminotransferase (U/L) & $<31$ & 43 & 45 \\
\hline Alanine aminotransferase $(\mathrm{U} / \mathrm{L})$ & $<34$ & 56 & 56 \\
\hline International normalized ratio & $0.9-1.2$ & 2.1 & 1.1 \\
\hline C-reactive protein & $0-0.5$ & $<0.03$ & $<0.03$ \\
\hline Albumin (g/dL) & $3.5-5.2$ & 2.4 & 3.7 \\
\hline Calcium (mg/dL) & $8.6-10.2$ & 4.3 & 8.9 \\
\hline Phosphorus (mg/dL) & $2.3-4.5$ & 1.2 & 3.9 \\
\hline Erythyrocyte sedimentation rate $(\mathrm{mm})$ & $<30$ & 7 & 25 \\
\hline Ferrum $(\mu \mathrm{g} / \mathrm{dL})$ & $37-145$ & 105 & 71 \\
\hline Total iron binding capacity $(\mu \mathrm{g} / \mathrm{dL})$ & $228-428$ & 139 & 146 \\
\hline Ferritin (ng/mL) & $13-150$ & 346.7 & 300.2 \\
\hline Folic acid $(\mathrm{ng} / \mathrm{mL})$ & $3.89-26.8$ & 2.24 & $>20$ \\
\hline
\end{tabular}


some of these. In general, malignancy is considered in cases of involuntary weight loss, and other causes, such as Celiac disease, can be overlooked. Up to 20 percent of Celiac patients may have abnormal liver function tests, which is known as Celiac hepatitis (18). Liver tests ALT, AST were also high in our case. After excluding the underlying viral and autoimmune hepatitis, abnormality in liver tests was thought to be secondary to Celiac disease.

The onset of diarrhea following the cessation of methotrexate due to psoriasis is thought to be a result of inflammatory bowel disease. In addition, pseudopolyps and ulcers seen in colonoscopy supported inflamatuary bowel disease.

In our opinion, celiac disease rarely conceive as a cause of chronic diarrhea in old age and diagnosis could be delayed.

At the point of this view, Celiac disease should be kept in mind in the presence of chronic diarrhea, weight loss and electrolyte imbalance in the geriatric age group, and it should be remembered that Crohn's disease may accompany Celiac disease.

\section{Ethics}

Informed Consent: Informed consent was taken from the patients.

Peer-review: Externally peer-reviewed.

\section{Authorship Contributions}

Surgical and Medical Practices: S.Ş., S.Ş., Z.F.S., R.V., B.D., S.F.A., F.Ö.K.K., B.G., O.Ö., Concept: : S.Ş., S.Ş., Z.F.S., R.V., B.D., S.F.A., Design: S.Ş., Data Collection or Processing: S.Ş., R.V., B.D., Analysis or Interpretation: S.Ş., Literature Search: S.Ş., Writing: S.Ş.

Conflict of Interest: No conflict of interest was declared by the authors.

Financial Disclosure: The authors declared that this study received no financial support.

\section{References}

1. Rubio-Tapia A, Ludvigsson JF, Brantner TL, Murray JA, Everhart JE. The prevalence of Celiac disease in the United States. Am J Gastroenterol 2012;107:1538-1544.
2. Choung RS, Larson SA, Khaleghi S, Rubio-Tapia, Ovsyannikova IG, King KS, Larson JJ, Lahr BD, Poland GA, Camilleri MJ, Murray JA. Prevalence and Morbidity of Undiagnosed Celiac Disease from a Community-Based Study. Gastroenterology 2017;152:830-839.

3. Schuppan D, Junker Y, Barisani D. Celiac disease: from pathogenesis to novel therapies. Gastroenterology 2009;137:1912-1933.

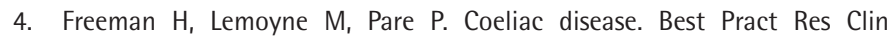
Gastroenterol 2002;16:37-49.

5. Vilppula A, Kaukinen K, Luostarinen L, Krekelä I, Patrikainen H, Valve R, Mäki $\mathrm{M}$, Collin P. Increasing prevalence and high incidence of Celiac disease in elderly people: a population-based study. BMC Gastroenterol 2009;29:49.

6. Freeman HJ. Clinical Spectrum of Biopsy-Defined Celiac Disease in the Elderly. Can J Gastroenterol 1995;9:42-46.

7. Greco L. Epidemiology of coeliac disease. Proceedings of the Seventh International Symposyum on Coeliac Disease. Tampere: Finland: 1996.

8. Cottone M, Cappello M, Puleo A, Cipolla C, Filippazzo MG. Familial association of Crohn's and coeliac diseases. Lancet 1989;2:338.

9. Cottone $M$, Marrone $C$, Casà $A$, Oliva L, Orlando A, Calabrese $E$, Martorana G, Pagliaro L. Familial occurrence of inflammatory bowel disease in Celiac disease. Inflamm Bowel Dis 2003;9:321-323.

10. Euler AR, Ament ME. Celiac sprue and Crohn's disease: an association causing severe growth retardation. Gastroenterology 1977;72:729-731.

11. Gillberg R, Dotevall G, Ahrén C. Chronic inflammatory bowel disease in patients with coeliac disease. Scand J Gastroenterol 1982;17:491-496.

12. Kitis G, Holmes GK, Cooper BT, Thompson H, Allan RN. Association of coeliac disease and inflammatory bowel disease. Gut 1980;21:636-641.

13. Yang A, Chen Y, Scherl E, Neugut Al, Bhagat G, Green PH. Inflammatory bowel disease in patients with Celiac disease. Inflamm Bowel Dis 2005;11:528-532.

14. Leeds JS, Höroldt BS, Sidhu R, Hopper AD, Robinson K, Toulson B, Dixon L, Lobo AJ, McAlindon ME, Hurlstone DP, Sanders DS. Is there an association between coeliac disease and inflammatory bowel diseases? A study of relative prevalence in comparison with population controls. Scand J Gastroenterol 2007;42:1214-1220.

15. Tursi A, Giorgetti GM, Brandimarte G, Elisei W. High Prevalence of Celiac Disease Among Patients Affected by Crohn's Disease. Inflamm Bowel Dis 2005:11:662-666.

16. Masachs M, Casellas F, Malagelada JR. Inflammatory bowel disease in Celiac patients. Rev Esp Enferm Dig 2007;99:446-450.

17. Casella G, D'Incà R, Oliva L, Daperno M, Saladino V, Zoli G, Annese V, Fries W, Cortellezzi C. Prevalence of Celiac disease in inflammatory bowel diseases: An IG-IBD multicentre study. Dig Liver Dis 2010;42:175-178.

18. Rubio-Tapia A, Murray JA. Liver involvement in celiac disease. Minerva Med 2008;99:595-604. 